\title{
Correction to: Performance assessment of water reuse strategies using integrated framework of urban water metabolism and water-energy-pollution nexus
}

\author{
Oriana Landa-Cansigno ${ }^{1} \cdot$ Kourosh Behzadian $^{2} \cdot$ Diego I. Davila-Cano $^{3} \cdot$ Luiza C. Campos $^{1}$ (1) \\ Published online: 26 August 2020 \\ (C) Springer-Verlag GmbH Germany, part of Springer Nature 2020
}

Correction to: Environmental Science and Pollution Research (2020) 27:4582-4597

https://doi.org/10.1007/s11356-019-05465-8

In Table 5, where it reads "Cardoso and Antunes (2017)", it should be "Chrispim and Nolasco (2017)"

In the reference list, where it reads "Cardoso CM, Antunes NM (2017) Greywater treatment using a moving bed biofilm reactor at a university campus in Brazil. J Clean Prod 142:290-296. https://doi.org/10.1016/j.jclepro.2016.07.162", it should be "Chrispim, MC, Nolasco, MA (2017) Greywater treatment using a moving bed biofilm reactor at a university campus in Brazil. J Clean Prod 142:290-296. https://doi.org/ 10.1016/j.jclepro.2016.07.162"

Publisher's note Springer Nature remains neutral with regard to jurisdictional claims in published maps and institutional affiliations.

The online version of the original article can be found at https://doi.org/ 10.1007/s11356-019-05465-8

Luiza C. Campos

1.campos@ucl.ac.uk

1 Civil, Environmental and Geomatic Engineering, University College London, Gower St, London WC1E6BT, UK

2 School of Engineering and Computing, University of West London, St. Mary's Rd, London W55RF, UK

3 Sistema Integrado de Tratamiento en los municipios de Rincón, SITRATA, Camino a San Jerónimo s/n, col. San Jeronimo, 36407, Purisima, Guanajuato, Mexico 